\title{
Psychometric Evaluation of WHOQOL-SRPB among Brazilian Adolescents
}

\author{
Miriam Raquel Wachholz Strelhow ${ }^{1}$ \\ Jorge Castellá Sarriera ${ }^{2}$
}

\begin{abstract}
A number of studies point to the relationship between spirituality and religiosity with health and well-being. However, there are few instruments to evaluate these aspects among adolescents. The objective of this study was to verify the psychometric properties of the Spirituality, Religiousness and Personal Beliefs module, part of the World Health Organization's Quality of Life Instrument (WHOQOL-SRPB) by analyzing evidence of validity and reliability among Brazilian adolescents. The participants were 1,248 Brazilian adolescents, between 12 and 18 years of age $(M=15.09, S D=1.77), 57.3 \%$ of whom were girls. Confirmatory factor analyses indicated that the eight-factor composition presents good fit indexes, and adequate reliability. Multi-group analyses indicated that there is factorial invariance by gender and age. It is concluded that the instrument presents evidence of validity and reliability with Brazilian adolescents. However, further studies are recommended especially considering the principal components analyses.
\end{abstract}

Keywords: spirituality, religiosity, measurement, psychometrics, adolescence

\section{Avaliação Psicométrica do WHOQOL-SRPB entre Adolescentes Brasileiros}

\begin{abstract}
Resumo: Estudos apontam a relação da espiritualidade e da religiosidade com a saúde e o bem-estar. Entretanto, são escassos os instrumentos para avaliação desses aspectos entre adolescentes. O objetivo deste estudo foi verificar as propriedades psicométricas do Módulo Espiritualidade, Religiosidade e Crenças Pessoais, integrante do Instrumento de Qualidade de Vida da Organização Mundial da Saúde (WHOQOL-SRPB), por meio da análise de evidências de validade e de fidedignidade entre adolescentes brasileiros. Participaram 1.248 adolescentes entre 12 e 18 anos $(M=15,09, D P=1,77), 57,3 \%$ meninas. As análises fatoriais confirmatórias indicaram que a composição do instrumento em oito fatores apresenta bons índices de ajustes e análise de confiabilidade adequada. Análises multigrupo indicaram que há invariância fatorial por sexo e idade. Conclui-se que o instrumento apresenta evidências de validade e fidedignidade com adolescentes brasileiros. Entretanto, recomendam-se novos estudos especialmente considerando a análise de componentes principais.
\end{abstract}

Palavras-chave: espiritualidade, religiosidade, medidas, psicometria, adolescência

\section{Evaluación Psicométrica del WHOQOL-SRPB entre Adolescentes Brasileños}

\begin{abstract}
Resumen: Los estudios apuntan a una relación de la espiritualidad y la religiosidad con la salud y el bienestar. Todavía son escasos los instrumentos para evaluar esos aspectos entre adolescentes. El objetivo del estudio fue verificar las propiedades psicométricas del módulo de Espiritualidad, Religiosidad y Creencias Personales, parte del Instrumento de Calidad de vida de la Organización Mundial de la Salud (WHOQOL-SRPB), a través de evidencias de validez y de fidedignidad entre adolescentes brasileños. Participaron 1.248 adolescentes, entre 12 y 18 años $(M=15,09, D E=1,77), 57,3 \%$ niñas. Los análisis factoriales confirmatorios indicaron que la composición de ocho factores tiene buenos índices de ajuste y análisis de confiabilidad adecuados. Los análisis multigrupo indicaron que existe invariancia factorial por sexo y edad. Se concluye que el instrumento presenta evidencias de validez y confiabilidad. Sin embargo, se recomiendan más estudios, especialmente considerando el análisis de los componentes principales.
\end{abstract}

Palabras clave: espiritualidad, religiosidad, medidas, psicometría, adolescencia

${ }^{1}$ Universidade de São Paulo, São Paulo-SP, Brazil
${ }^{2}$ Universidade Federal do Rio Grande do Sul, Porto Alegre-RS, Brazil

Article derived from the doctoral thesis of the first author under the supervision of the second, defended in 2017, in the Graduate Program in Psychology of Universidade Federal do Rio Grande do Sul. The study was funded by the CNPQ through a $\mathrm{PhD}$ scholarship (process 141014/2013-0) and by the FAPESP through a postdoctoral scholarship (process 2018/02178-5), both for the first author.

Correspondence address: Miriam Raquel Wachholz Strelhow. Universidade de São Paulo. Instituto de Psicologia. Avenida Prof. Mello de Morais, 1721, São Paulo-SP, Brazil. CEP 90.040-060. E-mail: raquelwch@gmail.com
The relationship between spirituality and religiosity with different psychological aspects, as well as health and well-being, has been described in several studies (Chen \& VanderWeele, 2018; Michaelson et al., 2019; Panzini et al., 2017). It is understood that spirituality is related to questions of meaning, meaning of life, not limited to religious beliefs or practices, while religiosity is more related the belief and practice of a certain religious faith shared by a group (Fleck, Borges, Bolognesi \& Rocha, 2003). A number of studies with adolescents indicate the experience of religiosity 
and spirituality and their relationship with happiness, satisfaction with life, well-being, in coping with stressful situations, as well as its impact on decision-making and on risk and protective behaviors (Jahn \& Dell'Aglio, 2017; Strelhow \& Henz, 2017).

Currently, an effort by researchers has been observed to provide measures that evaluate spirituality and its correlates, seeking to fill the lack of instruments in this area to allow for the advancement of new studies, especially in Brazil (Lucchetti, Lucchetti \& Vallada, 2013; Strelhow \& Sarriera, 2018; Zimpel, Panzini, Bandeira, Fleck \& Rocha, 2019). It should be noted, however, that the vast majority of instruments available in Portuguese have been adapted or developed for use in adults. Studies addressing these constructs in adolescence and/or childhood and the instruments available for that purpose in Brazil are still scarce (Strelhow \& Henz, 2017).

The scarcity of research studies with adolescents can be related to the ethical requirements to obtain the permission of those responsible, in addition to the acceptance of the adolescents themselves, but also to the challenge of developing instruments with appropriate language for this population (Fisher, 2016). In general, studies carried out with this age group use as variables the religion declared by the adolescent and the frequency of religious practice to assess religiosity (Silva, Giordani \& Dell'Aglio, 2017; Souza et al., 2012). However, it is understood that these measures are limited to assess the complexity of the phenomenon, which goes beyond being affiliated with a religion and practicing or not practicing that religion (Fleck et al., 2003). Few Brazilian studies with adolescents have used scales in research studies in this area (Jahn \& Dell'Aglio, 2017; Strelhow \& Sarriera, 2018).

The World Health Organization (WHO) has developed a specific module to assess spirituality, religiousness, and personal beliefs (WHOQOL-SRPB), based on the Quality of Life WHOQOL-100 instrument (Fleck et al., 2003). Originally, WHOQOL-100 assesses the Physical, Psychological, Level of independence, Social Relations, Environment and Spirituality, Religiousnes, and Personal Beliefs dimensions. However, initially this last dimension was evaluated based on a single subscale with 4 items. Based on research studies, the authors concluded that these were insufficient to assess these aspects and, therefore, the WHO developed WHOQOL-SRPB (Panzini, Maganha, Rocha, Bandeira \& Fleck, 2011).

The WHOQOL-SRPB instrument was created following the methodology already used by the WHO for the development of quality of life scales (WHOQOL). Initially, a number of specialists proposed factors for the evaluation of SRPB and, subsequently, 92 focus groups were conducted in 15 countries, including Brazil, in order to review these factors, as well as to verify their importance and the need to include new items (Panzini et al., 2011). The groups were composed of health professionals, patients with acute, chronic and terminal illnesses, patients in recovery, as well as atheists and members of any dominant religion in the participating centers or minority religious groups (Panzini et al., 2017).
After this process, the instrument was constituted by 32 items, grouped in eight factors identified below, with an item exemplifying each one: Spiritual connection (To what extent does any connection to a spiritual being help you to get through hard times?); Meaning and purpose in life (To what extent do you find meaning in life?); Experiences of awe and wonder (To what extent are you able to experience awe from your surroundings? [for example: nature, art, music]); Wholeness and integration (To what extent do you feel any connection between your mind, body and soul?); Spiritual strength (To what extent do you feel inner spiritual strength?); Inner peace (To what extent do you have inner peace?); Hope and optimism (How hopeful do you feel?); and Faith (To what extent does faith give you strength in daily life?).

An advantage of the WHOQOL-SRPB over other spirituality instruments is that it has already been widely used in Brazil with adult populations (Lucchetti et al., 2013) and in studies abroad (Chan, Verplanken \& Skevington, 2017; Panzini et al., 2017), showing good psychometric properties. Another important point of the instrument refers to the fact that WHOQOL-SRPB seeks not to link spirituality to religion, also encompassing people with agnostic or atheistic points of view (Fleck \& Skevington, 2007).

In a validation study of the Brazilian version of the instrument, the authors found good internal consistency $(\alpha=.96)$, as well as adequate test-retest reliability $(t=0.74, p=.463)$. Discriminative validity between believers and non-believers was also verified $(t=7.40 ; p<.001)$, with non-believers showing significantly lower mean values, convergent validity with the WHOQOL-Brief domains $(p<.001)$ indicating that those with higher means in WHOQL-Brief also present them in WHOQOL-SRPB, and convergent validity for the use of positive and religious coping strategies and discriminant validity for the use of negative religious coping strategies with the scale of Religious/Spiritual Coping-Brief (Panzini et al., 2011).

It is highlighted that this study was conducted with adults. No psychometric studies of the scale were found with Brazilian adolescents. Spirituality also plays an important role in the lives of adolescents, who are concerned with questions about the meaning of life and transcendence (King, Clardy \& Ramos, 2014). The study of these aspects and their implications for the development, health, and well-being of the adolescents is still an area that needs to be deepened (Strelhow \& Henz, 2017), and the availability of a specific instrument for this purpose can enable these advances. Thus, the objective of this study was to verify the psychometric properties of the Spirituality, Religiousness and Personal Beliefs Module, part of the World Health Organization's Quality of Life Instrument (WHOQOL-SRPB), through the analysis of evidence of validity and reliability among Brazilian adolescents. It seeks to test the hypothesis that the original model of the instrument, consisting of eight factors, remains valid for the assessment among adolescents. 


\section{Method}

\section{Participants}

The participants were 1,248 Brazilian adolescents of both genders, aged between 12 and 18 years old, who answered the survey through an online platform especially developed for this purpose. Of the participants, $57.3 \%$ were girls, and their mean age was 15.09 years old $(S D=1.77)$. Adolescents from 22 Brazilian states (of a total of 26 states), and from the Federal District participated. The states with the highest numbers of participants were the following: Rio Grande do Sul $(n=828,66.3 \%)$, São Paulo $(n=171,13.7 \%)$, Rio de Janeiro $(n=96,7.7 \%)$ Paraná $(n=27,2.2 \%)$, and the Federal District ( $n=24,1.9 \%)$.

Regarding religious or spiritual beliefs, $51.8 \%$ of the adolescents stated that they have a religion and practice it, $25.2 \%$ that they have a religion but do not practice it, $14 \%$ that they believe in superior forces (not necessarily in God), 4.3\% declared themselves atheists, and 4.6\% as agnostics. Regarding religious affiliation, $37.8 \%$ of the sample declared themselves as Catholics, $28.9 \%$ as Traditional evangelicals, $11.4 \%$ as Pentecostal evangelicals, $8 \%$ as Spiritists, and 4.7 as others. In addition, $3.9 \%$ of the sample claimed to have several religious affiliations, and $5.3 \%$ did not have any affiliation.

\section{Instruments}

Sociodemographic questionnaire. The participants answered sociodemographic questions.

Module - Spirituality, Religiousness and Personal Beliefs (WHOQOL-SRPB). The participants answered the Module - Religiousness and Personal Beliefs included in the World Health Organization's quality of life questionnaire. The WHOQOL-SRPB instrument consists of 32 items, divided into eight factors (four items each): Spiritual connection; Meaning and purpose in life; Experiences of awe and wonder; Wholeness and integration; Spiritual strength; Inner peace; Hope and optimism; and Faith. The items are answered on a scale from 1 to 5 , and the evaluation is carried out using a general index, as well as the eight factors, through the mean of the items.

The WHOQOL-SRPB in Portuguese was applied to a sample of 404 adults aged 18 to 84 years old $(M=42.85$ years old, $D P=13.91)$, and presented satisfactory psychometric qualities (precision and construct validity, discriminant and convergent validity, and criterion validity). Reliability through Cronbach's $\alpha$ was between .72 and .95 for the WHOQOL-SRPB domains, and .96 for the general index (Panzini et al., 2011).

As an initial stage for the development of this research, six focus groups were carried out with 58 adolescents, in which the instrument was presented and discussed item by item. After being approved by the adolescents, the instrument was adapted from its printed version to an online version. In this adaptation the recommendations of the International Test
Commission (2010) were followed, as described below. It was sought to maintain an equivalent control of the respondent in the possibility of ignoring or reviewing items, as well as maintaining the presentation of the items and the format of the answers in a way equivalent to the manual version. The psychometric analyses sought the reliability equivalence of the instrument as recommended by the International Test Commission. In addition, before the field research, a pilot study was carried out, seeking that the participants had the same conditions to complete the instrument, as the target population for the field study. In the pilot application, the participants were 81 adolescents aged 12 to 18 years old, of which $54.3 \%$ were girls. Data collection was carried out in two schools in the Metropolitan Region of Porto Alegre, one private and one public, after institutional agreement, with the completion of the Institutional Agreement, the parental authorization that was sent to their homes and returned signed by the person in charge, and the students' assent, confirmed in the term developed on the research site itself. The instrument was answered by the students in the computer labs of the respective schools, on a school shift. With the pilot study it was possible to verify the functioning of the website, as well as to verify the reliability of the instrument, through Cronbach' alpha.

\section{Procedures}

Data collection. Data collection was carried out online through an electronic form. The participants were invited to participate in the research study through invitations sent via virtual social networks and e-mails. In order to reach a larger number of participants, the research was also disseminated through invitations and posters in schools and religious institutions.

Data analysis. The analyses of this study seek to test the hypothesis that the original model of the instrument in eight factors remains valid for the evaluation among adolescents. Initially, the missing data were verified. The items had a missing percentage close to $3 \%$ or less, except for item 3.2 with a rate of $9.1 \%$. Thus, imputation by regression of the missing values was chosen. For the analysis, the sample was randomly divided in half. With the first half of the sample $(n=625)$, principal components analyses were performed to assess the content validity of WHOQOL-SRPB, and internal consistency analysis of the instrument and its factors using Cronbach's $\alpha$ values, with the SPSS 21 software. Principal Components Analysis (PCA) was chosen to verify in an exploratory manner the presence of latent factors in the set of items on the scale (Hair, Black, Babin, Anderson \& Tatham, 2009), considering it to be the first psychometric study with adolescents in Brazil. This analysis sought to carry out the same procedure adopted in the original study by Panzini et al. (2011), allowing for a comparison of the results.

Confirmatory Factor Analyses were performed with the second half of the sample $(n=623)$ to verify the adequacy of the scale to the model proposed in the literature and the findings in the principal components analysis. The maximum 
likelihood method was chosen considering the normal data distribution (kurtosis and symmetry between -1.00 and 1.00).

In the evaluation of the models, the Chi-square, the Comparative Fit Index (CFI), TLI (Tucker and Lewis Index), and the residual analysis with Root Mean Square Error of Approximation (RMSEA) and their confidence intervals were considered (Byrne, 2010). Acceptable models can be considered those with indexes greater than .90 for CFI and TLI, with values close to 1 being better. Regarding the residues (RMSEA), ideal values below .08 are indicated (Hair et al., 2009).

After analyzing the models, multi-group analyses were performed to verify the factorial invariance of the instrument considering the gender and age of the adolescents, with the total sample to guarantee a minimum of 200 participants in each analyzed group (Byrne, 2010). Multi-group analyses allow assessing whether the instrument's configuration and parameters are equivalent for different groups. These analyses are essential because they test whether the instrument can be used for comparison analyses of latent means between the groups (Damásio, 2013).

It was decided to test three measurement evaluation models: model 1 of configural invariance, evaluating the equivalence of the number of factors and items per factor; model 2 of metric invariance, which tests the equivalence of the items' factorial loads; and model 3 of scalar invariance, which indicates the equivalence between the intercepts of the items (Damásio, 2013). The difference between the CFIs $(\triangle \mathrm{CFI})$ that must not exceed .01 and between the RMSEA ( $\triangle$ RMSEA) indexes that must not exceed .015 were considered as comparative indexes to indicate comparability between the models. For the comparison by age, the sample was divided into three groups: 12 to 13 years old, 14 to 15 years old, and 16 to 18 years old.

\section{Ethical Considerations}

The research project was approved by the Research Ethics Committee of the Psychology Institute of Universidade Federal do Rio Grande do Sul, Opinion No. 1,176,831 (CAAE No. 45999215.0.0000.5334). When accessing the online research page, the participants were initially directed to a page containing the Free and Informed Consent Form (FICF) specifically designed for this research, containing an assent field for participation. For the participation of minors under 18 years old, the authorization of a responsible person was requested through identification of electronic address (e-mail) and agreement button. The procedures are in accordance with the criteria of ethics in research with human beings according to Resolution No. 466/2012 of the National Health Council.

\section{Results}

\section{Pilot study}

In the pilot study, the applicability of the research in the online format and the functioning of the website were verified. In this respect, the adolescents demonstrated an easy understanding of how the website works, and did not report any difficulties in answering most of the questions. In relation to the content of the questions, some specific doubts arose in relation to the more abstract terms present in items (2.1) "meaning in life" and (3.2) "beauty". Regarding reliability, it was verified that WHOQOL-SRPB obtained a Cronbach's alpha of .936 for the general scale, and alphas ranging from .582 to .938 in the following factors: Spiritual connection $=.901$; Meaning and purpose in life $=.726$; Experiences of awe and wonder $=.647$, being that, with the removal of item 3.2 , alpha would be increased to .717 ; Wholeness and integration $=.582$; Spiritual strength $=.921$; Inner peace $=.781 ;$ Hope and optimism $=.786$; Faith $=.937$, being that, with the removal of item 8.4 , it would be increased to .952 .

\section{Field study}

Principal Components Analysis (PCA). The instrument presented good adequacy measures for analysis with the assumptions of homoscedasticity and sphericity met $(\mathrm{KMO}=.964$, and Barlett's sphericity test $p<.001)$. The analyses were performed with data from half of the sample $(n=625)$, using Varimax rotation, and considering items with loads greater than .40 .

Initially, the analysis was performed considering the Kaiser normalization criterion (eigenvalues equal to or greater than 1). This freely estimated analysis pointed to a four-factor solution, which explained $62.28 \%$ of the variance. The four factors presented the following composition (considering the original nomenclature of the instrument's factors): Factor (1) Spiritual strength, Spiritual connection and Faith, added to items 4.4 and 3.2; Factor (2) Inner peace and items 4.2 and 4.3 of Wholeness and integration; Factor (3) included items of Hope and optimism and three items of Meaning and purpose life (2.3, 2.4, and 2.1); and Factor (4), the items of Experiences of awe and wonder and items 2.2. and 4.1.

It was decided to seek a new solution that could explain the content of the instrument with greater clarity. It was verified that, in the freely estimated solution, although four factors were selected for having eigenvalues greater than 1 , the next factor, which would be the fifth, obtained an eigenvalue of 0.99 . Thus, it was decided to verify the composition in five factors. This solution showed greater clarity in relation to the division of the instrument's contents (Table 1). 
Table 1

Principal Components Analysis WHOQOL-SRPB, in five factors $(n=625)$

\begin{tabular}{llll}
\hline & Components & \\
\hline & 1 & 2 & 3 \\
\hline
\end{tabular}

Factor 1 Faith

8.3 To what extent does faith give you strength in daily life?

5.3 How much does spiritual strength help you to live better?

.863

.863

.856

.853

8.2 To what extent does faith give you comfort in daily life?

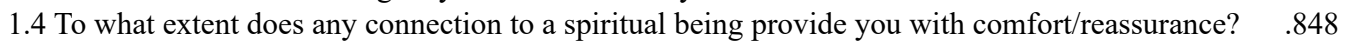

5.4 To what extent does your spiritual strength help you to feel happy in life?

5.2 To what extent can you find spiritual strength in difficult times?

1.1 To what extent does any connection to a spiritual being help you to get through hard times? $\quad .831$

1.2 To what extent does any connection to a spiritual being help you to tolerate stress? $\quad .773$

$\begin{array}{ll}8.4 \text { To what extent does faith help you to enjoy life? } & .773\end{array}$

$\begin{array}{ll}5.1 \text { To what extent do you feel inner spiritual strength? } & .727\end{array}$

1.3 To what extent does any connection to a spiritual being help you to understand others? $\quad .721$

4.4 How much do your beliefs help you to create coherence between what you do, think and feel? $\quad .651$

3.2 To what extent do you feel spiritually touched by beauty?

Factor 2 Inner peace

6.2 To what extent do you have inner peace?

6.1 To what extent do you feel peaceful within yourself?

6.3 How much are you able to feel peaceful when you need to??

6.4 To what extent do you feel a sense of harmony in your life?

4.2 How satisfied are you that you have a balance between mind, body and soul?

4.3 To what extent do you feel the way you live is consistent with what you feel and think?

Factor 3 Experiences of awe and wonder

3.1 To what extent are you able to experience awe from your surroundings? (e.g. nature, art, music)

3.4 To what extent are you grateful for the things in nature that you can enjoy?

2.2 To what extent does taking care of other people provide meaning of life for you?

3.3 To what extent do you have feelings of inspiration/excitement in your life?

4.1 To what extent do you feel any connection between your mind, body and soul?

Factor 4 Hope and optimism

7.3 To what extent does being optimistic improve your quality of life?

7.4 How able are you to remain optimistic in times of uncertainty?

7.1 How hopeful do you feel?

7.2 To what extent are you hopeful about your life?

Factor 5 Meaning and purpose in life

2.3 To what extent do you feel your life has a purpose?

2.1 To what extent do you find meaning in life?

2.4 To what extent do you feel you are here for a reason?

Explained variance (\%)

It is observed that Factor 1 remained composed of the three factors as in the initial analysis: Spiritual strength, Faith and Spiritual connection plus items 4.4 and 3.2, and so it was called "Faith". Factor 2 was composed of the items of Inner peace and two of Wholeness and integration, and the name "Inner peace" was maintained; likewise, it was decided to keep Factor 3 under the name of Experiences of awe and wonder, as it was formed by the three items of Experiences of awe and wonder added to items 2.2. and 4.1; Factor 4 was composed of the items of the Hope and optimism factor, with the Optimism items having greater weight in the factor; and Factor 5 , by three Meaning and purpose in life items.

It should be noted that item 2.2 loaded Factors 3 and 5 concurrently, with a higher load on factor 3. Originally, it would be in the Meaning and purpose in fife factor, but it obtained a higher load in the Experiences of awe and wonder factor. Item 2.4 also had a greater load on the Meaning and purpose in life factor, as expected, although with a load above .40 on the first factor, related to Faith.

\section{Reliability analysis}

Cronbach's alpha was considered to assess the reliability of the instrument. The total scale obtained a reliability value of .957. Table 2 shows the reliability of each factor, and if each item is deleted, in order to verify its contribution. Also the item-total correlation of the items for each factor, considering the solution proposed in the original eight-factor scale. It is observed that the alphas of seven factors were satisfactory $(>.70)$, and that only Factor 3 obtained a lower alpha, but with a value close to .70 . Table 2 also indicates that items 2.2. and 8.4 are the ones that least contribute to their respective factors, since their removal would increase reliability; however, they can be maintained in the factors, considering the contribution of the content they present, and the satisfactory total alpha of the factors in which they are included. 
Table 2

Reliability and item-total correlation of WHOQOL-SRPB according to the proposal of 32 items in eight dimensions $(n=625)$

\begin{tabular}{|c|c|c|c|}
\hline & Item & $\begin{array}{l}\text { Corrected Item- } \\
\text { Total correlation }\end{array}$ & $\begin{array}{l}\text { Alpha if the item } \\
\text { is removed }\end{array}$ \\
\hline \multirow{4}{*}{$\begin{array}{l}\text { Factor } 1 \\
\text { Spiritual } \\
\text { connection } \\
(\text { alpha }=0.906)\end{array}$} & 1.1 & .809 & .870 \\
\hline & 1.2 & .772 & .884 \\
\hline & 1.3 & .753 & .890 \\
\hline & 1.4 & .818 & .867 \\
\hline \multirow{4}{*}{$\begin{array}{l}\text { Factor } 2 \\
\text { Meaning and } \\
\text { purpose in life } \\
(\text { alpha }=0.758)\end{array}$} & 2.1 & .592 & .681 \\
\hline & 2.2 & .370 & .790 \\
\hline & 2.3 & .675 & .635 \\
\hline & 2.4 & .602 & .676 \\
\hline \multirow{4}{*}{$\begin{array}{l}\text { Factor } 3 \\
\text { Experiences of } \\
\text { awe and wonder } \\
(\text { alpha }=0.659)\end{array}$} & 3.2 & .370 & .656 \\
\hline & 3.3 & .453 & .583 \\
\hline & 3.4 & .483 & .563 \\
\hline & 3.1 & .479 & .568 \\
\hline \multirow{4}{*}{$\begin{array}{l}\text { Factor } 4 \\
\text { Wholeness and } \\
\text { integration } \\
(\text { alpha }=0.754)\end{array}$} & 4.1 & .593 & .673 \\
\hline & 4.3 & .554 & .696 \\
\hline & 4.4 & .531 & .713 \\
\hline & 4.2 & .536 & .706 \\
\hline \multirow{4}{*}{$\begin{array}{l}\text { Factor } 5 \\
\text { Spiritual strength } \\
(\text { alpha }=0.922)\end{array}$} & 5.1 & .774 & .914 \\
\hline & 5.2 & .814 & .900 \\
\hline & 5.3 & .860 & .884 \\
\hline & 5.4 & .830 & .894 \\
\hline \multirow{4}{*}{$\begin{array}{l}\text { Factor } 6 \\
\text { Inner peace } \\
(\text { alpha }=0.846)\end{array}$} & 6.1 & .687 & .803 \\
\hline & 6.2 & .747 & .776 \\
\hline & 6.3 & .665 & .813 \\
\hline & 6.4 & .634 & .825 \\
\hline \multirow{4}{*}{$\begin{array}{l}\text { Factor } 7 \\
\text { Hope and } \\
\text { optimism } \\
(\text { alpha }=0.806)\end{array}$} & 7.1 & .686 & .726 \\
\hline & 7.2 & .660 & .738 \\
\hline & 7.3 & .603 & .766 \\
\hline & 7.4 & .541 & .794 \\
\hline \multirow{4}{*}{$\begin{array}{l}\text { Factor } 8 \\
\text { Faith } \\
(\text { alpha }=0.946)\end{array}$} & 8.1 & .880 & .927 \\
\hline & 8.2 & .905 & .919 \\
\hline & 8.3 & .904 & .919 \\
\hline & 8.4 & .796 & .952 \\
\hline
\end{tabular}

In the composition of five factors indicated in the PCA, all the factors obtained alphas greater than .70: factor 1 (.96), factor $2(.84)$, factor $3(.74)$, factor $4(.81)$, and factor $5(.79)$. It is highlighted that all the items contributed to the factor, with item-total correlations higher than .40 , and no improvement in the alphas was detected with the removal of any item.

\section{Confirmatory Factorial Analysis (CFA)}

The CFA sought to test the hypothesis that the eightfactor model remains valid with Brazilian adolescents. Therefore, considering the PCA result, the two models were evaluated: Model 1) Model composed of eight factors (latent variables), with four items in each factor, according to the theoretical proposal of the authors; Model (2) The 32 items explained by five factors (latent variable), as indicated by the PCA. For this analysis, the other half of the sample $(n=623)$ participating in the research was selected.

In Table 3, it is observed that model 1 achieved acceptable adjustment indexes (CFI and TLI > .90), as well as a low residue index (RMSEA $<.08)$. In this model, all the parameters were significant and most of the items had factorial loads greater than .60, with the exception of items $2.2(.49), 3.2$ (.53), and $4.3(.55)$. In this model, the correlations between the latent factors were high, varying from .46 between factors 1 and 6 to .93 between factors 1 and 5 . The second highest correlation was between factors 5 and 8 (.90). Model 1 can be seen in Figure 1.

The second model was tested, considering the fivefactor proposal found in the PCA. For this model, five latent variables were placed and, related to them, the corresponding items. Table 3 shows that model 2 with five factors did not achieve adequate adjustments $(\mathrm{CFI}<.90)$.

Table 3

Adjustment indexes for the confirmatory models of the WHOQOL-SRPB scale

\begin{tabular}{|c|c|c|c|c|c|c|}
\hline & $X^{2}$ & Df & $p$ & TLI & CFI & $\operatorname{RMSEA}\left(\mathrm{CI}^{\mathrm{a}}\right)$ \\
\hline \multicolumn{7}{|l|}{ Confirmatory Factorial Analysis } \\
\hline Model 1. WHOQOL-SRPB, 8 factors & $1,522.364$ & 436 & $<.001$ & .909 & .920 & $.063(.060-.067)$ \\
\hline Model 2. WHOQOL-SRPB, 5 factors & $1,984.682$ & 454 & $<.001$ & .877 & .887 & $.074(.070-.077)$ \\
\hline \multicolumn{7}{|l|}{ Multi-group } \\
\hline \multicolumn{7}{|l|}{ WHOQOL-SRPB, 8 factors } \\
\hline \multicolumn{7}{|l|}{ Gender } \\
\hline Model 1 - Configural & $2,863.976$ & 872 & .000 & .917 & .927 & $.043(.041-.045)$ \\
\hline Model 2 - Metric & $2,878.332$ & 896 & .000 & .919 & .927 & $.042(.040-.044)$ \\
\hline Model 3 - Scalar & $3,052.509$ & 928 & .000 & .917 & .922 & $.043(.041-.045)$ \\
\hline \multicolumn{7}{|l|}{ Age } \\
\hline Model 1 - Configural & $3,875.442$ & 1,432 & .000 & .909 & .912 & $.037(.036-.038)$ \\
\hline Model 2 - Metric & $3,903.267$ & 1,456 & .000 & .910 & .912 & $.037(.035-.038)$ \\
\hline Model 3 - Scalar & $3,941.487$ & 1,488 & .000 & .912 & .912 & $.036(.035-.038)$ \\
\hline
\end{tabular}

Note. ${ }^{\mathrm{a}} \mathrm{CI}=95 \%$ Confidence Interval. 


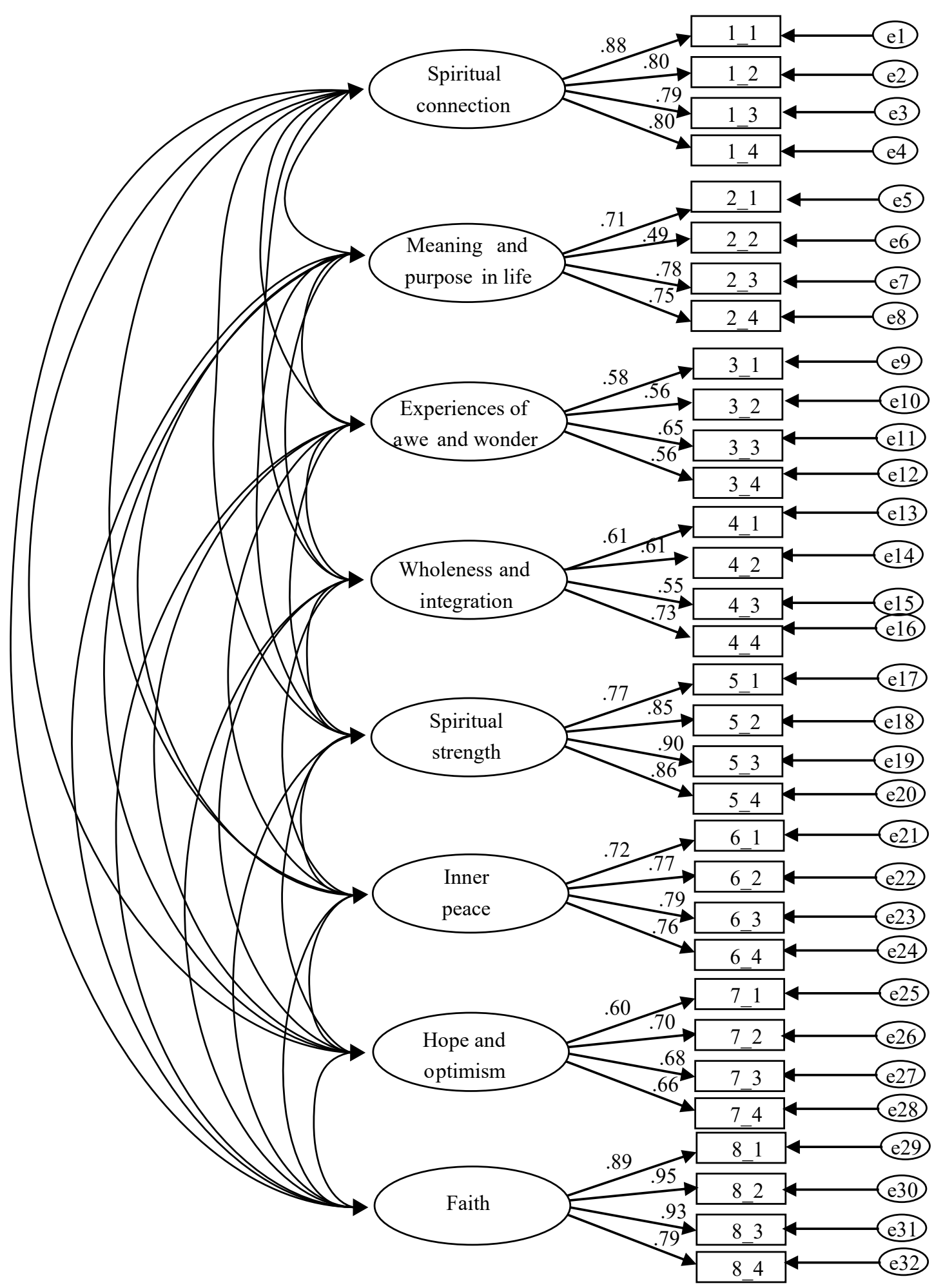

Figure 1. CFA model of WHOQOL-SRPB in eight dimensions and standardized loads.

\section{Multi-group Confirmatory Factorial Analysis}

Multi-group confirmatory analyses were performed to verify the equivalence of parameters (invariance) for gender and age in three groups (12-13, 14-15, and 16-18 years old). The analyses indicated that the differences between the CFI indexes $(\triangle C F I)$ did not exceed the value of .01 and that, for RMSEA ( $\triangle$ RMSEA), did not exceed the value of 015 between the three models tested, according to Table 3 . Thus, it can be considered that the factorial structure of the scale, the factorial weights of the items, as well as their intercepts are similar between boys and girls and between the three age groups. 


\section{Discussion}

From the pilot study, it can be seen that the adaptation to the online format presented good functioning and, in general, the items were well understood by the participants. It was verified that some participants found it difficult to understand the more abstract questions, specifically in relation to the expressions "meaning in life" (item 2.1) and "beauty" (3.2). Likewise, in the field application, item 3.2 was the one that obtained the highest percentage of missing data. However, almost $90 \%$ of the participants answered the item. The guideline of the group responsible for WHOQOL in Brazil (https://www. ufrgs.br/qualidep/) is that the instrument be used as it was formulated, without altering the existing questions. Thus, in this study it was decided to keep it in the original configuration of the instrument, with all the items applied. The psychometric analyses carried out demonstrated that maintaining item 3.2 does not decrease its psychometric functioning indexes.

Principal components analysis did not confirm the eightfactor composition hypothesis, initially pointing to four factors. In these four factors, some items did not remain together with the others of their factor as expected, so it was decided to explore in five factors, which indicated a clearer division of content. This five-factor formulation indicates that the contents of the factors, especially factors 1,5 , and 8 , are correlated. It is observed that these three factors bring faith as content, the belief that involves the relationship with a spiritual being. Theoretically, they can be understood as the dimension called by some authors of the vertical relationship of spirituality, of the human being with the transcendental aspect, while the other dimensions of the instrument seek to evaluate more horizontal and existential aspects (Marques, Sarriera \& Dell'Aglio, 2009; Shim, 2019).

This high correlation between the factors was also observed in the confirmatory analyses. The analyses indicated that the instrument composed of the eight dimensions presents good fit for the sample of adolescents, both considering the CFA, the multi-group analyses, and the reliability indexes, despite the high correlations, confirming the tested hypothesis. The first three factors were those that obtained the highest reliability indexes. It should be noted that the Experiences of awe and wonder factor obtained the lowest reliability in the study, which may be due to its more abstract character in the formulation of the items. A concern in this regard is whether the instrument works the same for adolescents who are in different phases of adolescence. The multi-group analyses carried out indicated that it does, and that, in this way, the instrument can be used for adolescents aged 12 to 18 years old. In this sense, it is suggested to carry out qualitative studies that will be able to verify in more depth the doubts raised by the adolescents in the pilot study in relation to some terms used in the instrument, as well as to deepen the issues evaluated by the instrument among adolescents.

Equivalence of the instrument for girls and boys was also observed, allowing its use for comparison of the latent means by gender. This analysis is important since a number of research studies show differences by gender in the experience of religiosity (Jahn \& Dell'Aglio, 2017), as well as in the relationship between spirituality and health (Michaelson et al., 2019).

No WHOQOL-SRPB psychometric studies were found with samples of adolescents for comparison with the data found, which reinforces that there is predominance of measures for evaluating spirituality and religiosity for adults and few aimed at adolescents, especially in Brazil (Lucchetti et al., 2013; Strelhow \& Henz, 2017). In this way, the contribution of the present study to the advances in this area of study is highlighted, with the evaluation of a more complex instrument, in addition to measures of declared religion and religious practice among adolescents. Future studies can also be carried out considering the short version of the scale, which was recently evaluated in psychometric terms in a sample of adults (Zimpel et al., 2019). The investment to provide instruments that assess spirituality is fundamental for conducting research studies with adolescents that address, for example, the relationship with aspects of health, quality of life, well-being, resilience and decisionmaking and behaviors (Chen \& VanderWeele, 2018; Michaelson et al., 2019; Panzini et al., 2017).

It is concluded that the WHOQOL-SRPB instrument presents some evidence of validity and reliability from the psychometric analyses performed, especially considering the Confirmatory Factor Analysis and the reliability analyses. However, new studies are recommended especially considering the principal components analysis that did not confirm the eight-factor structure. At this point, future studies may consider other forms of analysis, for example, opting for exploratory factor analysis other than PCA, verifying the composition of the factors through different methods.

It is important to note that the sample in this study was not representative, but for convenience, in which only adolescents with Internet access participated. This limitation imposes the need for precautions in generalizing the results. In this sense, it is also suggested that new studies seek diversified samples, such as, for example, in states that had little or no participation in this research, especially in the northern and northeastern states. In addition to studies with specific groups, such as adolescents with chronic diseases. It is also suggested that other studies may seek other evidences of validity not reached in this one, such as concurrent validity and stability of the instrument, with test-retest for example, or evaluating the difference in the functioning of the instrument for groups with different religious beliefs.

\section{References}

Byrne, B. M. (2010). Structural equation modeling with AMOS: Basic concepts, applications and programming (2nd ed.). New York, NY: Routledge.

Chan, K., Verplanken, B., \& Skevington, S. (2017). Cross cultural application of the WHOQOL-SRPB in the Chinese community with diverse spiritual affiliations. Social Indicators Research, 132(1), 291-312. doi:10.1007/s11205-016-1308-3 
Chen, Y., \& VanderWeele, T. J. (2018). Associations of religious upbringing with subsequent health and well-being from adolescence to young adulthood: An outcome-wide analysis. American Journal of Epidemiology, 187(11), 2355-2364. doi:10.1093/aje/kwy142

Damásio, B. F. (2013). Contribuições da Análise Fatorial Confirmatória Multigrupo (AFCMG) na avaliação de invariância de instrumentos psicométricos [Contributions of the Multigroup Confirmatory Factor Analysis in the invariance evaluation of psychometric tests]. Psico-USF, 18(2), 211-220. doi:10.1590/S1413-82712013000200005

Fisher, J. W. (2016). Assessing adolescent spiritual health and well-being (commentary related to Social Science \& Medicine - Population Health, ref: SSMPH-D-15-00089). Social Science \& Medicine - Population Health, 2, 304-305. doi:10.1016/j.ssmph.2016.04.002

Fleck, M.P.A., Borges, Z.N., Bolognesi, G., \& Rocha, N. S.(2003). Desenvolvimento do WHOQOL, módulo espiritualidade, religiosidade e crenças pessoais [Development of WHOQOL spirituality, religiousness and personal beliefs module]. Revista de Saúde Pública, 37(4), 446-455. doi:10.1590/ S0034-89102003000400009

Fleck, M. P., \& Skevington, S. (2007). Explaining the meaning of the WHOQOL-SRPB. Revista de Psiquiatria Clínica, 34(Suppl. 1), 146-149. doi:10.1590/S010160832007000700018

Hair, J. F., Jr., Black, W. C., Babin, B. J., Anderson, R. E., \& Tatham, R. L. (2009). Análise multivariada de dados [Multivariate data analysis] (A. S. Sant'Anna, Trans., 6th ed.). Porto Alegre, RS: Bookman.

International Test Commission. (2010). International guidelines on computer-based and internet-delivered testing. International Journal of Testing, 6(2), 143-171. doi:10.1207/ s15327574ijt0602_4

Jahn, G. M., \& Dell'Aglio, D. D. (2017). A religiosidade em adolescentes brasileiros [Religiosity in Brazilian adolescents]. Revista de Psicologia da IMED, 9(1), 38-54. doi:10.18256/2175-5027.2017.v9i1.1541

King, P. E., Clardy, C. E., \& Ramos, J. S. (2014). Adolescent spiritual exemplars: Exploring spirituality in the lives of diverse youth. Journal of Adolescent Research, 29(2), 186212. doi:10.1177/0743558413502534

Lucchetti, G., Lucchetti, A. L. G., \& Vallada, H. (2013). Measuring spirituality and religiosity in clinical research: A systematic review of instruments available in the Portuguese language. Sao Paulo Medical Journal, 131(2), 112-122. doi:10.1590/ S1516-31802013000100022
Marques, L. F., Sarriera, J. C., \& Dell'Aglio, D. D. (2009). Adaptação e validação da Escala de Bem-Estar Espiritual (EBE) [Adaptation and validation of Spiritual WellBeing Scale (SWS)]. Avaliação Psicológica, 8(2), 179186. Retrieved from http://pepsic.bvsalud.org/scielo. php?script=sci_arttext\&pid=S1677-04712009000200004

Michaelson, V., King, N., Inchley, J., Currie, D., Brooks, F., \& Pickett, W. (2019). Domains of spirituality and their associations with positive mental health: A study of adolescents in Canada, England and Scotland. Preventive Medicine, 125, 12-18. doi:10.1016/j.ypmed.2019.04.018

Panzini, R. G., Maganha, C., Rocha, N. S., Bandeira, D. R., \& Fleck, M. P. (2011). Brazilian validation of the Quality of Life Instrument related to spirituality, religion and personal beliefs. Revista de Saúde Pública, 45(1), 153-65. doi:10.1590/S003489102011000100018

Panzini, R. G., Mosqueiro, B. P., Zimpel, R. R., Bandeira, D. R., Rocha, N. S., \& Fleck, M. P. (2017). Quality of life and spirituality. International Review of Psychiatry, 29(3), 263282. doi:10.1080/09540261.2017.1285553

Shim, J. Y. (2019). Christian spirituality and smartphone addiction in adolescents: A comparison of high-risk, potential-risk, and normal control groups. Journal of Religion and Health, 58(4), 1272-1285. doi:10.1007/s10943-018-00751-0

Silva, D. G., Giordani, J. P., \& Dell 'Aglio, D. D. (2017). Relações entre satisfação com a vida, com a família e com as amizades e religiosidade na adolescência [Relations between life satisfaction, family and friendship satisfaction and religiosity in adolescence]. Estudos Interdisciplinares em Psicologia, 8(1), 38-54. doi:10.5433/2236-6407.2017v8n1p38

Souza, L. D. M., Maragalhoni, T. C., Quincoses, M. T., Cruzeiro, A. L. S., Ores, L., Silva, R. A., \& Pinheiro, R. T. (2012). Bemestar psicológico de jovens de 18 a 24 anos: Fatores associados [Psychological well-being of young people 18 to 24 years of age and associated factors]. Cadernos de Saúde Pública, 28(6), 1167-1174. doi:10.1590/S0102-311X2012000600015

Strelhow, M. R. W., \& Henz, K. G. (2017). Spirituality and religiosity related to the well-being of children and adolescents: A theoretical and empirical approach. In J. C. Sarriera \& L. M. Bedin (Eds.), Psychosocial well-being of children and adolescents in Latin America: Evidence-based interventions (pp. 27-45). Cham, Switzerland: Springer.

Strelhow, M. R. W., \& Sarriera, J. C. (2018). Evidências de validade do Índice de Religiosidade de Duke(P-DUREL) entre adolescentes [Validity evidence of the Duke Religion Index (P-DUREL) among adolescents]. Avaliação Psicológica, 17(3), 330-338. doi:10.15689/ap.2018.1703.14630.06 
Zimpel, R. R., Panzini, R. G., Bandeira, D. R., Fleck, M. P., \& Rocha, N. S. (2019). Psychometric properties of the WHOQOL-SRPB BREF, Brazilian Portuguese version. Brazilian Journal of Psychiatry, 41(5), 411-418. doi:10.1590/1516-4446-2018-0083

Miriam Raquel Wachholz Strelhow is a postdoctoral researcher of Universidade de São Paulo, São Paulo-SP, Brazil.

Jorge Castellá Sarriera is a Professor of Universidade Federal do Rio Grande do Sul, Porto Alegre-RS, Brazil.

\section{Authors' Contribution}

All the authors made substantial contributions to the conception and design of this study, to data analysis and interpretation, and to the manuscript review and approval of the final version. All the authors assume public responsibility for content of the manuscript.

Received: May. 23, 2019

1st Revision: Sep. 18, 2019

2nd Revision: Feb. 03, 2020

3rd Revision: Jun. 25, 2020

Approved: Jun. 26, 2020

How to cite this article:

Strelhow, M. R. W., \& Sarriera, J. C. (2020).

Psychometric evaluation of WHOQOL-SRPB among Brazilian adolescents. Paidéia (Ribeirão Preto), 30, e3035.doi:https://doi.org/10.1590/1982-4327e3035 